\title{
COVID 19 PANDEMIC SHIFTING THE JOB SATISFACTION LANDSCAPE AMONG EMPLOYEES
}

\author{
Takupiwa Nyanga \\ Department of Human Resource Management, Julius Nyerere School of Social Sciences, \\ Great Zimbabwe University, Masvingo, Zimbabwe \\ takupiwa@gmail.com \\ Andrew Chindanya \\ Pro-Vice Chancellor, Great Zimbabwe University, Masvingo, Zimbabwe \\ andychindanya@gmail.com
}

\begin{abstract}
The purpose of this study was to analyze the implication of COVID 19 on job satisfaction among workers in SMEs in Zimbabwe. A purely qualitative study was undertaken to establish how COVID 19 affects the attitude of workers towards their work. The study utilized a multiple case study design with an interview being utilized as the main data collection tool. Data was collected from a sample of $20(n=20)$ participants who were selected using purpose sampling approach. Data was analyzed using a combination of thematic analysis and descriptive analysis. The study found out that COVID 19 significantly affects job satisfaction among workers in SMEs. COVID 19 resulted in the decrease in workers' salaries, employment opportunities and job security. The study also found out that COVID 19 increases employee stress due to fear of contracting the disease and propel poor working conditions for workers in SMEs. It was therefore recommended that employers should lay special emphasis on ways and strategies that protect workers from contracting COVID 19. The measures and strategies which can be used to promote employee satisfaction during the COVID 19 pandemic include among others giving workers risk allowances, creating a safe work environment, provide personal protective equipment to workers and employing flexible work arrangements.
\end{abstract}

Keywords: Corona Virus, COVID 19, Job satisfaction, Employees, SMEs.

\section{INTRODUCTION}

Within a diminutive space of time the COVID 19 epidemic grew to become one of the most debated global catastrophes with shocking health, business and socio-economic impact in all the countries. Nyanga and Zirima (2020) indicated that almost all the businesses throughout the world were directly and/ or in-directly affected by the pandemic. Businesses irrespective of size and complexity face the challenges of colossal alterations in demand of their products and services, supply chains, transport and logistics of goods, mobility and protection of employees (Adams-Prassl et al., 2020; Bachelet, 2020; 
ILO, 2020). Studies (Meri, 2020; Chirombe et al., 2020; Trifu, 2020; Bloom et al., 2020; Benassy-Quere et al., 2020) have shown that COVID 19 has destabilized operations of various businesses throughout the world and caused untold suffering among workers. It is essential, and exigent for organizations to ensure that the normal psycho-social wellbeing of their employees is maintained, so that they continue to perform their tasks effectively and efficiently during the COVID 19 pandemic propelled economic recession. ILO (2020) indicated that organizations should ensure that systems that protect workers from contracting the corona virus are put in place. Businesses should also regularly evaluate the effects of COVID 19 on workers, employers and another key stakeholder. It is in the interest of an organisation to protect its customers, suppliers and employees from contracting the corona virus. ILO (2020) information on the labour market impact of the COVID-19 pandemic showed the devastating effect of COVID 19 on workers in the informal economy. Studies and International labour organisations have confirmed that COVID 19 has caused serious operational challenges for various organizations by putting a lot of restrictions to the movement of people inside and outside work premises. Job satisfaction being one of the key factors to organizational performance, growth and survival needs to be checked and monitored regularly. The purpose of this research is to examine the influence of the COVID 19 contagion on job satisfaction among workers.

\section{LITERATURE REVIEW}

The COVID-19 pandemic has caused serious negative implications on the supply of the labour force and its conditions of service across the globe (Adams-Prassl et al., 2020). The negative effects are predominantly severe for younger employees, especially those with wobbly labour relationships. The evidence shows that there is need for employers to respond quickly and address the consequences of the pandemic on workers. Poor work conditions and low wages were found to be having devastating effects on the level of satisfaction of workers and their psychological wellbeing (Nyanga et al., 2018; Nyanga, 2018; Nyanga and Sibanda, 2020). Owing the importance of job satisfaction on employee performance it becomes imperative to establish whether the COVID 19 pandemic significantly affect it or not. Job satisfaction is mainly influences by the job, tasks, superiors, the modification of the psychological contract between the company and the human resource (Rousseau and Mclean-Parks, 1993; Thompson and Bunderson, 2003), and its dynamic evolution adapted to the working life of the workers. According to Chirombe et al (2020) COVID 19 epidemic has changed or modified workers' jobs, tasks, and systems of supervision, psychological contracts and other work-related activities. It has however remained unclear whether the modifications the COVID 19 epidemic has caused have an effect on job satisfaction or not. 
A study carried out by Gazioglu and Tansel (2006) established a strong relationship between employee happiness and several personal and labor issues such as delegation, autonomy, salary and wages and the psychological wellbeing. Studies also show that economic cycles disturb job satisfaction and employee motivation. Job satisfaction is one of the factors that require to be managed and treated in a manner that ensures that workers maintain their zeal and energy to expend their energy towards realizing organizational goals. During economic recession and distress, strategic organizations ensure that their workers are appropriately satisfied and ready to assist their organizations to gain a competitive advantage and protect it from the effects of economic depression. Workers expend their energy, knowledge and skills to the best of their ability if and only if they are satisfied with their jobs and motivated by the way the organization treats them (Nyanga and Tapfumaneyi, 2019). Preda (2020) argues that organisations and governments cannot afford to ignore the spread of the COVID 19 pandemic because it has instigated a chain of swift alterations in people's personal, professional and economic lives. The pandemic has affected all the economic and social facets of almost all the businesses throughout the world. Employees had to change their work practices and embrace newly adopted work practices such as holding virtual meetings, flexible work arrangements and others. Nyanga and Zirima (2020) indicated that several workers also lost their employment and opportunities for growth and promotion due to the emergency of the COVID 19 pandemic.

Job satisfaction is an important factor for the survival and growth of companies during economic recession (Nyanga et al., 2018) because labor demands play a key role in how workers perform their work. The lower a worker's labor expectations are, the more likely the worker will be satisfied by his/her work. Job satisfaction is subject to various social, economic, technological, political, personal and related factors such as working conditions (Nyanga et al., 2012), self-confidence (Benabou et al., 2000), cultural differences. Many researchers have studied job satisfaction for decades (Nyanga et al., 2012; Nyanga et al., 2018; Mukuvisi et al., 2019) and developed a pattern of the causes, effects and consequences of job satisfaction, but the unexpected and unanticipated emergency of the COVID 19 scourge which is ravaging the global economy and destabilizing the global workforce has created a new knowledge gap which needs to be filled. It is therefore the purpose of this study to close this knowledge gap by analyzing the extent to which the COVID 19 pandemic affects job satisfaction among workers in Zimbabwe.

\section{RESEARCH METHODOLOGY}

The research utilized a purely qualitative research approach, with a multiple case design being utilized. Qualitative research approach was adopted because of its ability to provide researchers with an in- 
depth analysis of issues. Though being criticized for being subjective in nature, the qualitative approach provides researchers with well-grounded data. The multiple case study design was opted for because it gave the researchers an opportunity to triangulate and validate data by analyzing data collected from more than one organization. Organizations in Masvingo also operate in different geographical areas hence the use of multiple design help in validating the collected data. Some organizations operate from residential areas, others in industrial areas while others operate from the central business district of Masvingo city. The population of the study encompassed all workers from organizations in the city of Masvingo. It was very difficult for the researchers to establish the number of the study units since a significant number of organizations especially SMEs were operating in an informal fashion without any registration. The researchers could therefore not establish the number of workers in Masvingo urban. Using purposive sampling technique five organizations were selected to participate in the study. 20 participants were also selected to participate in the study. Convenience sampling technique was utilized to select the participants. The researchers interviewed those workers whom they found at their workstations during their visit. Data was collected over a period of one month using face to face interviews. Both the researchers and interviewees observed the World Health Organization's COVID 19 guidelines to avoid the spread of the corona virus. Data was analyzed using thematic data analysis method. Themes and sub-themes were identified at the data collection and analysis stages. All the participants' responses were slotted in the identified themes and sub-themes for further scrutiny and analysis. The next section of the research looks at the findings of the study.

\section{FINDINGS}

\subsection{Demographic information of participants}

Participants of the study comprised 13 male and 7 female employees drawn from five institutions in Masvingo urban. 9 participants were below 35 years of age, 7 were above 35 but below 45 while 4 were aged 45 and above. In terms of marital status; 11 were married, 6 were single, 2 widowed and 1 divorced. The participants had the following educational levels: ordinary level and below $(n=3)$, diploma $(n=7)$ and degree $(n=10)$. It shows organisations in Masvingo urban have a diversity of workers in terms of age, educational qualification, marital status and work experiences. Diversity of workers is one of the facets that propel organizational performance, survival and growth because it promotes the generation of various ideas drawn from people of different experiences and dispositions. The biographical data of participants is consistent with the biographical data of participants who participated in the study that was done by Nyanga and Sibanda (2020). 


\subsection{Effects of COVID 19 on Factors of Job Satisfaction}

\section{Compensation}

The study revealed that the COVID 19 pandemic significantly affects workers' salaries, wages, benefits and other conditions of employment. Most organizations especially SMEs find it very difficult to raise enough money to cover all their operational expenses such as salaries, wages electricity and water bills due to the COVID 19 restrictions which has reduced the business time by at least two hours and also put restrictions to movement of people. Most organizations lost a lot of business due to COVID 19 hence they find it difficult to fulfill the remuneration needs and demands for their workers. In line with this view participants had this to say; participant 9 remarked; "Our employer is failing to raise enough money to cover our salary and wage bills because his business drastically dropped when a plethora of measures to curb COVID 19 were introduced." Participant 6, "COVID 19 restrictions barred a lot of organisations especially SMEs from operating smoothly because of their failure to meet the WHO COVID 19 prevention guidelines" Failure by business to generate a lot of profit resulted in most SMEs failing to meet their salaries and wages obligations. This therefore implies that the COVID 19 pandemic directly and indirectly affect job satisfaction among workers because of the negative impact it poses on workers' salaries and wages. Studies (Nyanga, 2018; Nyanga et al., 2012; Nyanga et al., 2020) have shown that salaries and wages play a very critical role in promoting employee satisfaction among workers in the developing world, workers in armed conflict societies and workers in depressed economic environments. The unstable economic environment which has basically become a permanent feature in Zimbabwe, coupled with COVID 19 incapacitated most organizations from raising enough financial resources to cover their operational costs.

\section{Job security}

The study also found out that most workers in SMEs lost jobs because of COVID 19. The COVID 19 pandemic caused a lot of losses of jobs because most organizations were no longer able to pay workers meaningful if any salaries and wages. Some workers were retrenched by their employers while others decided to leave employment after realizing that the salaries, they were getting could not meet their financial obligations such as paying rent and also buying basic food items for themselves and their families. The study also showed that those workers who also remained in employment were living in fear of losing their jobs, which consequently led to low job satisfaction among workers. In line with findings some of the participants had this to say, "Job satisfaction among employees has been seriously affected by the COVID 19 induced lack of job security. Many workers have lost jobs, and more are bound to lose due to the COVID 19 pandemic." "Job insecurity, coupled with the fear of contracting 
COVID 19 has adversely affected job satisfaction among employees in Masvingo city, Zimbabwe." The results are in sync with Maslow's Hierarch of Needs theory which indicated that job security was a key antecedent to job satisfaction and motivation. The findings are also consistent with Nyanga et al. (2018) who established that job security was one of the main factors that influence job satisfaction in volatile and ambiguous socio-economic environments. Furthermore, ILO (2020) warned that the unrelenting strident drop-in business hours worldwide due to the COVID 19 pandemic imply that several employees in both the informal and formal sectors are bound to lose their livelihood.

\section{Psycho-social stability}

Mukuvisi et al. (2019) indicated that stress is one of the principal precipitators of low job satisfaction among workers working in a health threatening and hazardous area. Consistent with Mukuvisi et al. (2019), COVID 19 possess a lot of threats to workers' health and safety, which consequently lead to low job satisfaction among workers in various sectors of the economy. The COVID 19 pandemic demands that workers observe the WHO COVID 19 pandemic guidelines such as regularly washing hands, putting on masks and social distancing. Observing the guidelines on its own is stressful since it is something that is new and unusual in their work culture. The global, regional and local news on the devastating effects of COVID 19 also scare workers to the extent of triggering their blood pressure and lowering their job satisfaction and motivation levels. Almost $50 \%$ of the news items and promotional messages on social and traditional media are on COVID 19, which in way demonstrates to workers that it is a deadly disease which is worth to spend money and resources on. The news and promotional messages instill fear of contracting the disease in workers which has consequently led a number of workers to self-quarantine and absent themselves from work. Nyanga and Zirima (2020) argued that COVID 19 causes anxiety, depression and various psycho-social disorders among workers and their employers. Furthermore, Bachelet (2020) says that workers, employers and consumers are facing COVID 19 induced shocks. The fear of becoming infected by the virus disturbs and destabilizes workers' psycho-social dispositions.

\section{Employment and promotion opportunities}

COVID 19 deprives job seekers and workers employment and promotion opportunities because most organizations focus on survival, maintaining and keeping their organizations afloat. Little if any energy is put towards the promotion and creation of more positions in organizations because of the operational pressures exerted on organizations by the COVID 19 epidemic and the volatile and economically unstable environment. Studies (Mukuvisi et al 2019) have shown that workers view employment and promotion opportunities as key factors that promote job satisfaction among workers. The fact that the 
COVID 19 pandemic has limited such opportunities and only opened them in health promotion sectors, has left workers in in various organisations and industries devastated and with a negative attitude towards their work and their employers. One of the participants remarked, "The corona virus has reduced my job satisfaction because it has reduced almost all the promotion opportunities that were available for me." Another participant also remarked, "Since January 2020 there had been no employment opportunities because most companies had put to a halt all their recruitment, selection and placements activities due to the COVID 19 pandemic. Such a move has made workers in SMEs to develop a negative attitude towards their work." In summary it shows that COVID 19 significantly affect job satisfaction among workers in various organizations and industries. Most SMEs are expected to be the engines and drivers of the economies in the developing world but the emergence of the COVID 19 pandemic made it extremely difficult if not impossible.

\section{CONCLUSION}

Human capital is the most critical and essential assets and pillars responsible of anchoring the growth and survival of any organization during economic distress. The value and importance of workers in promoting the success and survival of organizations make employee satisfaction a key success factor for any organization. Satisfied workers are better prepared to expend their energy towards meeting organizational goals than those who are not satisfied. The main purpose of the study was to establish the ramifications of the COVID 19 pandemic on job satisfaction among workers. The study concluded that the nature and financial positions of most organizations make workers vulnerable to the effects of the COVID 19 pandemic. COVID 19 affects almost all the key facets that propel job satisfaction such as salaries and wages, employment and promotion opportunities, psycho-social wellbeing of workers, job security, autonomy and others. COVID 19 dwindle most organizations and industries market share and sources of income to the extent of leaving organizations with very little financial resources to meet their financial obligations such as salaries and wages. The unbalancing financial and income statements make it very difficult for most organisations to hire more manpower but instead they downsize to remain with favourable balance sheets. Workers experience a lot of psycho-social disorders due to the emergency and rapid growth of the COVID 19 corona virus, which consequently lead to low job satisfaction among workers in Zimbabwe and beyond. Considering the conclusion made it is therefore recommended that employers should provide psycho-social support to workers during the COVID 19 pandemic period. Employers can also introduce more financial and non-financial benefits to workers so as to cushion them from the effects of high inflation and other effects of the COVID 19 pandemic. 


\section{Nyanga, T., Chindanya, A. \\ COVID 19 PANDEMIC SHIFTING THE JOB SATISFACTION LANDSCAPE AMONG EMPLOYEES}

\section{REFERENCES}

Adams-Prassl, A., Boneva, T., Golin, M., \& Rauh, C. (2020). The large and unequal impact of COVID19 on workers. VoxEU. org. Library Catalog: VoxEU. url: https://voxeu. org/article/large-andunequalimpact-covid-19-workers.

Bachelet. M. (2020) COVID-19 and its Impact on Businesses and Workers, International Organization of Employers Digital Dialogue. UN High Commissioner for Human Rights.

Benabou, R. (2000). Unequal Societies: Income Distribution and the Social Contract," American Economic Review, American Economic Association, vol. 90(1), pages 96-129

Benassy-Quere, A, R., Marimon, J., Pisani-Ferry, L Reichlin, D., Schoenmaker and B Weder di Mauro (2020). Europe needs a catastrophe relief plan, www.VoxEU.org.

Bloom, N., Bunn, P., Chen, S., Mizen, P., and Smietanka, P., (2020). The Economic Impact of Coronavirus on UK businesses: Early Evidence from the Decision Maker Panel, www.VoxEU.org.

Chirombe T, Benza ,S., Munetsi E. and Zirima, H. (2020). Coping Mechanisms Adopted by People During the COVID 19 Lockdown In Zimbabwe. Business and Management Excellence, 10 (Special Issue 1), 33-45.

Gazioglu, S. and Tansel, A. (2006). Job Satisfaction in Britain: Individual and Job Related Factors Applied Economics, 38 (10), 1163-1171.

ILO (2020). As Job Losses Escalate, Nearly Half of Global Workforce at Risk of Losing Livelihoods, ILO News.

Meri, M. (2020). New Trends in Human Resource Management and Knowledge Management in the Health Sector beyond Corona Virus - A Practical Model. Business and Management Excellence, 10 (Special Issue 1), 5-21.

Mukuvisi, P. F., Nyanga, T., \& Mashavira, N. (2019). Strategies of Liberating Private Voluntary Organizations (PVO) Employees from Work-Related Stress: Evidence from PVO Employees in Harare. IIMS Journal of Management Science, 10(3), 118-127.

Nyanga, T. (2018). Examining the Usefulness of Job Satisfaction Theories in Armed Conflict Society. Amity Global Human Resource Management Review, 8(2), 40-48.

Nyanga, T., Mudhovozi, P., \& Chireshe, R. (2012). Causes and effects of role ambiguity as perceived by human resource management professionals in Zimbabwe. Journal of Social Sciences, 30(3), 293303.

Nyanga T. and Sibanda, R., (2020). Consequences of Armed Conflict Thorny to Job Satisfaction among Workers in Armed Conflict Societies: A Case of Tete Province in Mozambique, Journal of Vietnam Academy of Social Sciences, 21 (2).

Nyanga T., Sibanda, R. and Kruger J.W. (2018). Financial Growth and Stability in Armed Conflict Society: Does Job Satisfaction Play a Role?, Amity Journal of Management Research, 3 (1), 27-39.

Nyanga, T., Sibanda, R. and Kruger, J.W. (2019). Destruction of the Economic Infrastructure by Armed Conflict: Implications on Job Satisfaction among Workers in Juba, South Sudan, Amity Journal of Economics, 4 (2).

Nyanga, T. and Tapfumanei Christian Shelfa. "Collective bargaining: a catalyst for dispute resolution between employers and employees in the retail industry in urban Mutare." Ushus Journal of Business Management 18.1 (2019): 1-13. 
Nyanga, T., \& Zirima, H. (2020). Reactions of small to medium enterprises in masvingo, zimbabwe to covid 19: Implications on productivity. Business Excellence and Management, 10 (Special Issue 1), 22-32.

Preda, I. (2020). Challenges In The Management Of Emergency Public Procurement Performed In Romania to Combat The Covid-19 Pandemic. Business Excellence and Management, 10 (Special Issue 1), 67-87.

Rousseau, D.M. and Parks, I.M. (1993). The Contracts of Individuals and Organizations. Research in Organizational Behavior, 15, 41-43.

Thompson. J. A and Bunderson. J.S. (2003). Violations of Principle: Ideological Currency in the Psychological Contract, The Academy of Management Review, 28(4):571-586.

Trifu, A. (2020). Happiness Facing to the Perfidious and Invisible Challenge of Covid-19. Business Excellence and Management, 10 (Special Issue 1), 60-66. 